\title{
TIPE DATA CHAR
}

\author{
Zalmi Randa Ramadhan \\ 185100034 \\ Fakultas Komputer \\ randa.student@umitra.ac.id
}

\begin{abstract}
Tipe data char di dalam bahasa $\mathrm{C}$ digunakan untuk menampung 1 digit karakter, entah itu berupa huruf maupun angka. Variabel yang didefinisikan untuk menampung tipe data char membutuhkan 1 byte memory. Secara teknis, char ini dikodekan dari charset ASCII.

Disini huruf berupa sebuah konstanta bertipe char, bukan lagi variabel seperti sebelumnya. Mengenai perbedaan antara variabel dengan konstanta, sudah pernah kita bahas dalam beberapa tutorial sebelum ini: Cara Pembuatan Konstanta dalam Bahasa C, dan Pengertian Variabel dan Cara Penulisan Variabel Bahasa C.

Tipe data Char adalah tipe data yang hanya bisa diisi dengan 1 karakter saja. Karakter ini harus ditulis diantara tanda kutip. Karena hanya bisa diisi dengan 1 karakter saja, tipe data char hanya membutuhkan 1 byte memory ( 1 byte $=8$ bit).

Selain itu, variabel bertipe data char juga bisa diisi dengan urutan karakter ASCII. Ini akan lebih mudah dijelaskan dengan menggunakan contoh kode program.

Di dalam compiler FreePascal, selain tipe data Char, didukung juga tipe data AnsiChar dan wide char.
\end{abstract}




\section{A. PENDAHULUAN}

Bahasa pemprograman, merupakan adalah suatu komando atau perintah yang dibuat manusia untuk membuat komputer menjadi memiliki fungsi tertentu. bahasa pemrograman ini adalah suatu susunan aturan penulisan (sintaks) yang membentuk kode kode yang kemudian akan diterjemahkan oleh program kompiler menjadi bahasa rakitan (assembly) dan terus diolah hingga dimengerti oleh mesin. Komputer hanya mengerti bahasa mesin.

Bagi pemula, belajar bahasa pemprograman memang sulit, namun bukan berarti itu penghalang bagi kita untuk enggan belajar. Di Fakultas Informatika yang notabene khusus mempelajari ilmu-ilmu komputer sekalipun, tidak semua mahasiswanya pandai dalam bahasa pemrograman tertentu. Hal itu dikarenakan tidak semua orang mempunyai pemikiran dan kreativitas yang sama sehingga daya nalar terhadap sebuah bahasa pemrograman didapatkan hasil yang berbeda-beda untuk setiap orang. Perlu anda ketahui bahwa Program yang ditulis dengan menggunakan bahasa pascal mempunyai ciri yang terstruktur sehingga mudah dipahami maupun dikembangkan oleh pemogram.

Pada suatu bahasa pemrograman umumnya telah menyediakan tipe - tipe data yang sederhana ( simple ) maupun yang terstruktu. Termasuk di bahasa pascal.

\section{B. PEMBAHASAN / STUDI KASUS}

Tipe data sederhana adalah tipe data dasar, karena hanya mampu menyimpan satu nilai tiap satu variabelnya.

2.1.1 Integer

Tipe

Ukuran memori

(dalam byte)

Ukuran memori

Jangkauan nilai

BYTE

1

$0 . .255$

SHORTINT

1

$-128 . .127$

INTEGER

2

$-32768 . .32767$

WORD

2

$0 . .65535$

LONGINT

4

$-2147483648 . .2147483647$

Jenis data ini merupakan nilai bilangan bulat, yang terdiri atas integer positif, integer negatif dan nol. Pada TURBO PASCAL jenis data ini di bagi atas beberapa bagian. (lihat tabel 1) table

1. Jenis data integer 
Operator Integer terdiri atas :

,,+- *, DIV dan MOD

Var

$$
\begin{aligned}
& \text { Jumlah : byte; } \\
& \text { Begin } \\
& \text { Jumlah := 32; } \\
& \text { WriteLn('Nilai } \\
& \text { JUMLAH = ',Jumlah); } \\
& \text { writeln('NUR_FADILAH'); } \\
& \text { readln; } \\
& \text { End. }
\end{aligned}
$$$$
\text { Hasilnya: }
$$

\section{Real Karakter}

Nilai konstanta numeric real berkisar dari 1E-38 sampai 1E+38. E menunjukkan nilai 10 pangkat, dan tipe data ini menempati memori sebesar 6 byte.

Tipe data karakter Merupakan urut-urutan dari karakter yang terletak diantara tanda petik tunggal. Nilai data string akan menempati memori sebesar banyaknya karakter string ditambah dengan 1 byte. Bila panjang dari suatu string didalam deklarasi variable tidak disebutkan, maka dianggap panjangnya adalah 255 karakter.

Contoh :

Var

$$
\text { Nilai1, Nilai2 : real ; }
$$

Begin

Nilai1 : =

12345678901.2345;

Nilai2 $:=12345$;

Writeln ('Nilai 1=', Nilai1);

Writeln (' Nilai 2 =', Nilai2);

writeln('NUR FADILAH'); readln;
Output dari contoh program diatas :

\author{
C. ID SECURITY \\ QWTD4452377-ASP-5244107
}

\section{KESIMPULAN}

Bahasa pemprograman assambly dibagi atas 3 tipe data, yaitu tipe data terstruktur, tipe data sederhana, dan tipe data pointer

- Tipe data sederhana dibagi atas tiga, yaitu tipe data interger, real karakter, dan tipe data bolean

- Tipe data terstruktur terbagi atas tipe data array, dan tipe data record

Tipe data pointer
merupakan tipe data yang
berisi alamat pada register.

\section{E. DISKUSI}

Apakah artikel ini berguna ?

Nanda : menurut saya artikel ini sangat bergunakarena saya dapat mempelajari lebih dalam lagi tentang Tipe Data Char.

\section{Apakah kekurangan artikel ini?}

Nauli : menurut saya kekurangan artikel ini adalah peletakan kata-kata nya masih sedikit barangkatan.

End. 


\section{F. REFERENCE}

[1] O. M. Febriani and A. S. Putra, "Sistem Informasi Monitoring Inventori Barang Pada Balai Riset Standardisasi Industri Bandar Lampung," J. Inform., vol. 13, no. 1, pp. 90-98, 2014.

[2] A. S. Putra, "Paperplain: Execution Fundamental Create Application With Borland Delphi 7.0 University Of Mitra Indonesia," 2018.

[3] A. S. Putra, "2018 Artikel Struktur Data, Audit Dan Jaringan Komputer," 2018.

[4] A. S. Putra, "ALIAS MANAGER USED IN DATABASE DESKTOP STUDI CASE DB DEMOS."

[5] A. S. Putra, "COMPREHENSIVE SET OF PROFESSIONAL FOR DISTRIBUTE COMPUTING."

[6] A. S. Putra, "DATA ORIENTED RECOGNITION IN BORLAND DELPHI 7.0."

[7] A. S. Putra, "EMBARCADERO DELPHI XE 2 IN GPUPOWERED FIREMONKEY APPLICATION."

[8] A. S. Putra, "HAK ATAS KEKAYAAN INTELEKTUAL DALAM DUNIA TEKNOLOGY BERBASIS REVOLUSI INDUSTRI 4.0.”

[9] A. S. Putra, "IMPLEMENTASI PERATURAN

PERUNDANGAN UU. NO 31

TAHUN 2000 TENTANG DESAIN INDUSTRI BERBASIS INFORMATION
TECHNOLOGY."

[10] A. S. Putra, "IMPLEMENTATION OF PARADOX DBASE."

[11] A. S. Putra, "IMPLEMENTATION OF TRADE SECRET CASE STUDY SAMSUNG MOBILE PHONE."

[12] A. S. Putra, "IMPLEMENTATION PATENT FOR APPLICATION WEB BASED CASE STUDI WWW. PUBLIKLAMPUNG. COM."

[13] A. S. Putra, "IMPLEMENTATION SYSTEM FIRST TO INVENT IN DIGITALLY INDUSTRY."

[14] A. S. Putra, "MANUAL REPORT \& INTEGRATED DEVELOPMENT

ENVIRONMENT BORLAND DELPHI 7.0."

[15] A. S. Putra, "PATENT AS RELEVAN SUPPORT RESEARCH."

[16] A. S. Putra, "PATENT FOR RESEARCH STUDY CASE OF APPLE. Inc."

[17] A. S. Putra, "PATENT PROTECTION FOR APPLICATION INVENT."

[18] A. S. Putra, "QUICK REPORT IN PROGRAMMING."

[19] A. S. Putra, "REVIEW CIRCUIT LAYOUT COMPONENT

REQUIREMENT ON ASUS NOTEBOOK."

[20] A. S. Putra, "REVIEW TRADEMARK PATENT FOR INDUSTRIAL TECHNOLOGY BASED 4.0." 
[21] A. S. Putra, "TOOLBAR COMPONENT PALLETTE IN OBJECT ORIENTED PROGRAMMING."

[22] A. S. Putra, "WORKING DIRECTORY SET FOR PARADOX 7."

[23] A. S. Putra, "ZQUERY CONNECTION

IMPLEMENTED

PROGRAMMING

STUDI

CASE PT. BANK BCA Tbk."

[24] A. S. Putra, D. R. Aryanti, and I. Hartati, "Metode SAW (Simple Additive Weighting) sebagai Sistem Pendukung Keputusan Guru Berprestasi (Studi Kasus: SMK Global Surya)," in Prosiding Seminar Nasional Darmajaya, 2018, vol. 1, no. 1, pp. 85-97.

[25] A. S. Putra and O. M. Febriani, "Knowledge Management Online Application in PDAM Lampung Province," in Prosiding International conference on Information Technology and Business (ICITB), 2018, pp. 181-187.

[26] A. S. Putra, O. M. Febriani, and B. Bachry, "Implementasi Genetic Fuzzy System Untuk Mengidentifikasi Hasil Curian Kendaraan Bermotor Di Polda Lampung," SIMADA (Jurnal Sist. Inf. dan Manaj. Basis Data), vol. 1, no. 1, pp. 21-30, 2018.

[27] A. S. Putra, H. Sukri, and K. Zuhri, "Sistem Monitoring Realtime Jaringan Irigasi Desa (JIDES) Dengan Konsep Jaringan Sensor Nirkabel," IJEIS (Indonesian J. Electron. Instrum. Syst., vol. 8, no. 2, pp.
221-232.

[28] D. P. Sari, O. M. Febriani, and A. S. Putra, "Perancangan Sistem Informasi SDM Berprestasi pada SD Global Surya," in Prosiding Seminar Nasional Darmajaya, 2018, vol. 1, no. 1, pp. 289-294. 